\title{
High-Density Algal Photobioreactors Using Light-Emitting Diodes
}

\author{
Choul-Gyun Lee and Bernhard Ø. Palsson* \\ Department of Chemical Engineering, University of Michigan, \\ Ann Arbor, Michigan 48109
}

Received December 23, 1993/Accepted June 17, 1994

Lack of high-density algal photobioreactors (PBR) has been a limitation in exploiting the biotechnological potential of algae. Recent developments of highly efficient light-emitting diodes (LED using gallium aluminum arsenide chips) have made the development of a small LEDbased PBR possible. We have calculated theoretical values of gas mass transfer requirements and light-intensity requirements to support high-density algal cultures for the $680 \mathrm{~nm}$ monochromatic red light from LED as a light source. A prototype PBR has been designed based on these calculations. A cell concentration of more than $2 \times$ $10^{9}$ cells $/ \mathrm{mL}$ (more than $6.6 \% \mathrm{v} / \mathrm{v}$ ), cell doubling times as low as $12 \mathrm{~h}$, and an oxygen production rate as high as 10 $\mathrm{mmol}$ oxygen/L culture/h were achieved using on-line ultrafiltration to periodically provide fresh medium. (c) 1994 John Wiley \& Sons, Inc.

Key words: Chlorella vulgaris - light-emitting diodes (LED) • oxygen production • photobioreactor (PBR)

\section{INTRODUCTION}

Algal biotechnology is drawing increasing interest due to its potential as a source of valuable pharmaceuticals, pigments, carbohydrates, and other fine chemicals. ${ }^{4,7,9,13,39}$ Currently, its application is being extended to the areas of waste water treatment ${ }^{6,10,14}$ and agriculture. ${ }^{23}$ Further, the ability to regenerate oxygen from carbon dioxide is key to the design of an efficiently controlled ecological life-support system. ${ }^{21,31}$ However, lack of suitable photobioreactors (PBR) makes the cost of algally-derived compounds higher than those derived by chemical synthesis, ${ }^{3,37}$ and thus has prevented widespread use of algal cultures.

Important factors in achieving high-density productive algal culture are light, gas exchange, medium supply, and biological limitations. ${ }^{17,34,35}$ To effectively exploit the commercial potential of algae, a cheap, durable, reliable, and highly efficient light source is needed. If the light source has a narrow spectral output that overlaps the photosynthetic absorption spectrum, the emission of light at unusable frequencies would be eliminated and therefore the overall energy conversion improved. One light source that meets these criteria is a light-emitting diode (LED) ${ }^{38}$ LED are light and small enough to fit into virtually any PBR, they have a very long life-expectancy, and their electrical efficiency is so high that heat generation is minimized. LED

* To whom all correspondence should be addressed. have a half-power band-width of $20-30 \mathrm{~nm}$ which can be matched with photosynthetic needs. However, the light intensity of conventional LED is too low to be used in PBR. Recently, double-power double-heterostructure (DDH) gallium aluminum arsenide (GaAlAs) chips which can emit light at much higher intensity and efficiency have been developed. ${ }^{40}$ These DDH GaAlAs LED arrays can emit photon fluxes as high as $900 \mu \mathrm{mol} / \mathrm{m}^{2} / \mathrm{sec}$, ${ }^{1}$ which is sufficient to support photosynthesis in many $\mathrm{C}_{3}$ plants. ${ }^{46}$

For the past decade, it has been shown that high-density photoautotrophic algal cultures can be established. A number of PBR have been introduced to obtain productive highdensity photosynthetic cultures. Most of them were thin panel or tubular PBR, ${ }^{22,26,33,36,42,44}$ but modified stirredtank ${ }^{43,48}$ or hollow-fiber $\mathrm{PBR}^{47}$ were also tested. Newconcept PBR with internal illuminations through optical fibers $5,15,24,27,41$ have also been employed. The key design challenges were to maximize surface-to-volume ratio, to provide a more efficient light source, to deliver the light more efficiently to the culture, and to provide a more effective mass transfer of gases. Direct comparison of the performance of these PBR is difficult, but the general performance characteristics can be enumerated. The maximum biomass concentrations achieved were normally in the range of 5-6 g/L. ${ }^{22,27,42,43,44,48}$ Some PBR were able to obtain higher cell concentrations than $10 \mathrm{~g} / \mathrm{L},{ }^{15,41}$ with the highest reported cell concentration being $20 \mathrm{~g} / \mathrm{L} \cdot{ }^{33}$ Few studies have reported the oxygen production rate. All the PBR reported used full-spectrum light source, such as sunlight or metal halide lamps. Here we report that red LED can be used in PBR to obtain high cell densities and high oxygen production rates.

\section{PHOTOBIOREACTOR DESIGN CONSIDERATION}

The major factors that must be considered in the design of high-density PBR are light delivery and distribution, gas transfer into and out of the reactor, maintenance of medium components in balance, and prevention of accumulation of potentially detrimental secondary metabolites.

\section{Goals}

The goal is to achieve maximal biomass production rates using LED. The highest cell density previously obtained in 
our laboratory was $1 \times 10^{9}$ cells $/ \mathrm{mL}(\approx 3 \% \mathrm{v} / \mathrm{v})^{15}$ by using a 1,000-W xenon lamp as the light source. The oxygen production rate of this PBR system was between 4-6 $\mathrm{mmol} / \mathrm{L}$ culture/ $\mathrm{h}$. The goal is to achieve equal or higher culture density and oxygen production rate using red LED as compared to a full-spectrum light source.

\section{Estimation of the Specific Oxygen Production Rate (SOPR)}

Each mol of chlorophyll is reported to produce $50-400 \mathrm{~mol}$ of oxygen per $h,{ }^{29}$ and the per-cell average chlorophyll content is in the range of $0.5-1.0 \mathrm{fmol}^{25}$ The product of these numbers will yield a range of expected per-cell oxygen productivity; $25-400 \mathrm{fmol} \mathrm{O}_{2} / \mathrm{cell} / \mathrm{h}$.

A simple experiment with a small, illuminated couvette with a dissolved oxygen (DO) electrode was employed to verify this range. The measured SOPR fell within the estimated range. The SOPR was between 5-200 fmol/cell/h, decreasing with increasing cell concentration as expected due to mutual shading (Table I). Since the measured SOPR was inversely proportional to the cell concentration, the design challenge is to deliver and distribute the light efficiently to minimize the effect of mutual shading. The SOPR will have to be high at high-cell densities if the design of a PBR is to be optimized for oxygen production. A target in situ SOPR is $100 \mathrm{fmol}$ of oxygen per cell per $\mathrm{h}$ at a cell concentration of $1 \cdot 10^{9}$ cells $/ \mathrm{mL}$.

\section{The Light Requirement}

Enough light to produce $100 \mathrm{fmol}$ of oxygen/cell/h has to be provided. According to the Z-scheme photosynthesis, ${ }^{12} 8$ mol of photons are required to generate $1 \mathrm{~mol}$ of oxygen. One mol of $680 \mathrm{~nm}$ photons per $\mathrm{h}$ is equivalent to about 50 W. As a result, each cell needs to experience $40 \mathrm{pW}$ equivalent of photons to achieve the targeted SOPR of $100 \mathrm{fmol} /$ cell/h.

The desired cell density and the specific illuminated surface area are then used to compute the required light flux. For the $10^{9}$ cells $/ \mathrm{mL}$ culture and $1.0 \mathrm{~cm}^{2}$ illuminated area per $\mathrm{cm}^{3}$ culture, one needs to provide $40 \mathrm{~mW} / \mathrm{cm}^{2}$ or more because the maximum photosynthetic efficiency of Chlorella has been reported to be in the range of $32 \%$ to $54 \% .^{20,28,32}$ A closely packed LED array (90 LED on a $2^{\prime \prime}$ $\times 4^{\prime \prime}$ printed circuit board, spaced about $0.76 \mathrm{~cm}$ apart) could provide a light intensity as high as $25 \mathrm{~mW} / \mathrm{cm}^{2}$ on each illuminating surface of the PBR.

\section{Light Delivery and Distribution}

In addition to the light source, the light delivery and the light distribution inside a PBR are key factors in PBR design. Light should be delivered so that photon loss is minimized, heat generation by the light source eliminated, and potentially harmful wavelengths filtered. By using LED, all of these problems are circumvented. The best way to minimize photon loss is to have internal illumination. The small volume characteristics of LED makes this possible. Furthermore, their high efficiency and sharp spectrum eliminate the need for a cooling system and filter. Therefore, LED represent perhaps the optimal light source for PBR.

Good light distribution will maximize the overall light utilization by minimizing mutual shading as well as photoinhibition. It should be noted that any light not absorbed or not used in photosynthesis will be converted into thermal energy.

\section{Gas Transfer}

Gas transfer is an important issue in PBR design; carbon dioxide needs to be supplied and oxygen generated removed. Carbon dioxide is the carbon source utilized for photosynthesis. ${ }^{30}$ Depending on the type of species, $\mathrm{CO}_{2}$ can be absorbed in dissociated $\left(\mathrm{HCO}_{3}{ }^{-}\right.$or $\left.\mathrm{CO}_{3}{ }^{-2}\right)$ or undissociated form $\left(\mathrm{CO}_{2}\right.$ or $\left.\mathrm{H}_{2} \mathrm{CO}_{3}\right){ }^{2}$ In either case, carbon dioxide needs to be dissolved into the culture broth. Oxygen is a product of photosynthesis as well as an inhibitor of algal growth. Thus, the produced oxygen needs to be removed to prevent oxygen from reaching inhibitory level.

The target of SOPR is $100 \mathrm{fmol} \mathrm{O}_{2} / \mathrm{cell} / \mathrm{h}$. For $10^{9}$ cells/ $\mathrm{mL}, 100 \mathrm{mmol}$ oxygen needs to be removed per $\mathrm{L}$ of culture

Table I. Specific oxygen production rate in units of $\mathrm{fmol} / \mathrm{cel} / \mathrm{h}$ at various light intensities and cell concentrations

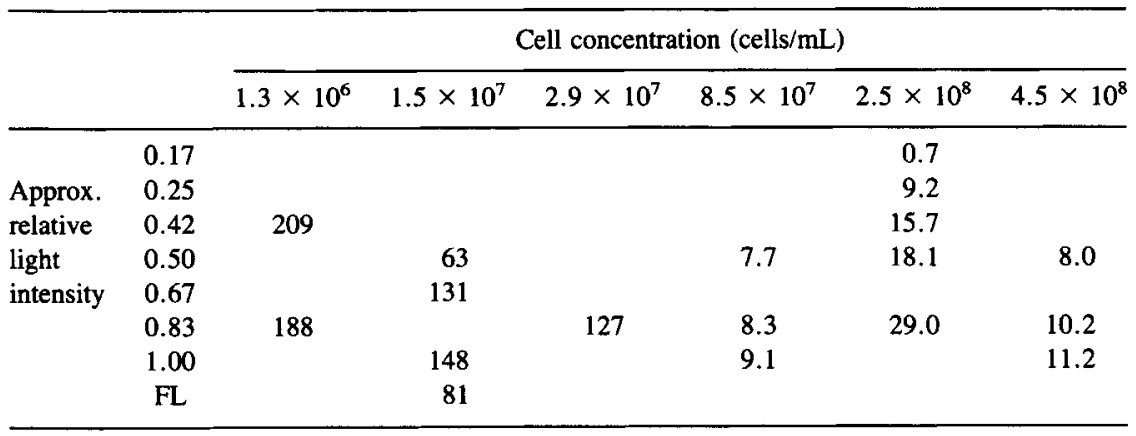

Light intensities are expressed as relative intensities to the maximum (the intensity of $2.1 \mathrm{~V} /$ device $=1$ ). A $22 \mathrm{~W}$ cool-white circline fluorescent light (General Electric Co.), or FL, was used as a full-spectrum control. 
per $h$. To achieve this rate of oxygen transfer, the volumetric mass transfer coefficient $\left(k_{L} a\right)$ needs to be larger than 80 $\mathrm{h}^{-1}$. However, SOPR may be reduced as the cell concentration increases due to the light limitation in a high-density culture.

One way to remove $100 \mathrm{mmol}$ of oxygen/L culture/h is by internal sparging. The overall mass transfer rates by sparging were calculated for two different bubble sizes (1 $\mathrm{mm}$ and $3 \mathrm{~mm}$ in diameter) ${ }^{18}$ Both could give the required oxygen transfer $\left(k_{L} a\right.$ of about $200 \mathrm{~h}^{-1}$ and $100 \mathrm{~h}^{-1}$, respectively, at the aeration rate of $20 \mathrm{~m} / \mathrm{h}$ ). The results from the above calculations, as well as those for typical bioreactors, ${ }^{8}$ are summarized in Table II.

\section{Mixing}

Good fluid mixing is important for achieving high cell concentration in a PBR. Good mixing can keep the cells in suspension, eliminate thermal stratification, help nutrient distribution, and improve gas exchange. Furthermore, mixing can reduce the degree of mutual shading and lower the probability of photoinhibition. The last reason is perhaps the most important one for requiring the right extent of mixing to achieve a successful PBR. Proper mixing in the direction perpendicular to flow (parallel to light path) will significantly reduce the mutual shading and thus increase the portion of the cells exposed to the light. This mixing will also move the cells close to the illuminated surface into the center of the PBR, which will give these photonsaturated cells the opportunity to use up all the absorbed light energy for photosynthesis before they are exposed to the light again. This mixing, in turn, will also provide the same opportunity to the cells in the center (that already used up the absorbed photons) to "see" the light. As a result, a proper mixing may significantly improve overall lightutilization efficiency. Sparging will improve overall lightutilization efficiency in two ways: (1) existence of air bubbles will increase light penetration depth, and (2) rising motion of bubbles will induce some degree of mixing tangential to the flow direction.

\section{On-Line Supply of Medium Components}

Yet another important parameter in PBR design is to keep all medium components in balance with growth and photosynthetic requirements. Discussion of this topic can be

Table II. Overall mass transfer coefficient under various conditions

\begin{tabular}{|c|c|}
\hline System configuration & $k_{L} a(1 / \mathrm{h})$ \\
\hline Stagnant water (specific surface area of $1 \mathrm{~cm}^{2} / \mathrm{cm}^{3}$ ) & 7.56 \\
\hline Prototype PBR ( $20 \mathrm{~m} / \mathrm{h}$ aeration, $3 \mathrm{~mm}$ diam. bubble) & 110 \\
\hline Prototype PBR ( $20 \mathrm{~m} / \mathrm{h}$ aeration, $1 \mathrm{~mm}$ diam. bubble) & 200 \\
\hline Bubble fermentor (no agitation, $20 \mathrm{~m} / \mathrm{h}$ aeration) & $10-30$ \\
\hline Conical flasks (shaking at $200 \mathrm{rpm}$, no aeration) ${ }^{\mathrm{a}}$ & $25-100$ \\
\hline $\operatorname{CSTR}(500 \mathrm{rpm}, 20 \mathrm{~m} / \mathrm{h} \text { aeration })^{\mathrm{a}}$ & 325 \\
\hline CSTR $(750 \mathrm{rpm}, 20 \mathrm{~m} / \mathrm{h} \text { aeration })^{\mathrm{a}}$ & 1,000 \\
\hline $\operatorname{CSTR}(1,680 \mathrm{rpm}, 20 \mathrm{~m} / \mathrm{h} \text { aeration })^{\mathrm{a}}$ & 2,650 \\
\hline
\end{tabular}

${ }^{2}$ Data from ref. 8. found elsewhere. ${ }^{16}$ The on-line replenishment of medium (supply of medium components as well as removal of any potentially harmful secondary metabolites) was achieved either by dialysis or ultrafiltration using Cell-Pharm model BR170 (molecular weight cut-off of $70 \mathrm{kDa}$, UniSyn Technologies, San Diego, CA). The difference between the two methods is the application of external force for ultrafiltration; the dialysis mode supplies the medium components purely by diffusion.

Ultrafiltration was preferred because it was faster and thus disturbed gas measurement less. By applying vacuum (about $400 \mathrm{mmHg}$ ) to the shell side of the ultrafiltration cartridge, replenishment of $200 \mathrm{~mL}$ of medium (about three times the volume of medium in the PBR system used) could be achieved in $10 \mathrm{~min}$.

\section{PHOTOBIOREACTOR DESIGN AND CONSTRUCTION}

LED were chosen as a light source for all the reasons stated above, such as high electrical energy conversion efficiency, sufficient light intensity, and small volume and weight characteristics (which will make the most efficient internal illumination possible). For the required mass transfer rate, internal sparging was employed.

Black polycarbonate plate (Ain Plastics, Inc., Mount Vernon, NY) and black norprene tubing (Cole-Parmer Instrument Co., Niles, IL) were chosen as materials used for PBR construction and the tubing material because of their biocompatibility, chemical and mechanical properties, opaqueness, oxygen impermeability, and autoclavability.

From a series of simple preliminary experiments with various geometries, a PBR with a vertical rectangular slabshaped illumination chamber was found to be suitable. This shape meets all the stated criteria, such as good light distribution with the smallest possible dark volume, proper mixing without damaging cells by shear stress, and minimization of wall growth.

The volumes of the illumination chamber were either 80 $\mathrm{cm}^{3}$ or $52 \mathrm{~cm}^{3}$, depending on the depth of culture $(1.55 \mathrm{~cm}$ and $1.00 \mathrm{~cm}$, respectively). Both illumination chambers had the same illumination area of about $100 \mathrm{~cm}^{2}\left(8 \mathrm{in}^{2}\right.$, sum of the two sides). Each illumination chamber had two LED units on each side which consisted of either 24 LED for low-intensity light delivery or 90 LED for high-intensity light delivery. The two LED units were mounted in such a way that the LED on the different sides of the illumination chamber were alternated to have better light distribution inside the illumination chamber. The power to the LED units was increased as the cell concentration increased with time.

Mass transfer was achieved via internal sparging through four 3-mm diameter nozzles (a half-inch apart from each other) located at the bottom of the illumination chamber. At a gas flow rate of $100 \mathrm{~mL} / \mathrm{min}$ with a liquid circulation rate of $100 \mathrm{~mL} / \mathrm{min}$, calculated superficial velocities were 0.42 $\mathrm{cm} / \mathrm{sec}$ and $0.67 \mathrm{~cm} / \mathrm{sec}$, depending on the thickness of the illumination chamber. 
The resulting PBR had a gas/liquid phase separation module allowing for gas exit (Fig. 1). Introducing sparging added some complexity to the system because the gas analyzer used had to have a hermetically sealed gas phase to measure the gas consumption/production rate accurately (see Materials and Methods section).

\section{MATERIALS AND METHODS}

\section{Cell Line and Culture Medium}

C. vulgaris (UTEX 398, recently renamed as C. kessleri ${ }^{19}$ ) was obtained from The Culture Collection of Algae at UTEX (Austin, TX) on proteose agar. The $\mathrm{N}-8$ culture medium was used without modification. ${ }^{45}$

\section{LED, Light Measurements, and Power Supplies}

Red DDH GaAlAs LED were obtained from Quantum Devices Inc. (Barneveld, WI). These LED have narrow spectral outputs that peak at wavelengths of $680 \mathrm{~nm}$. The LED were powered by simple DC power supplies (GP-105, GoldStar Precision, Cerritos, CA) with constant voltage between $1.7 \mathrm{~V}$ and $2.1 \mathrm{~V}$ per device, except one point where $2.4 \mathrm{~V}$ were applied.

The light intensity of the LED units was measured by a silicon photo cell (Model 0560.0500, Testoterm GmbH \& Co., Germany). The light intensities of a high-intensity LED unit were about 3 and $12 \mathrm{~mW} / \mathrm{cm}^{2}$ when powered at 1.7 and $2.1 \mathrm{~V}$, respectively.

\section{Culture Conditions}

Two different types of LED units were constructed: a lowintensity unit with 24 LED in a $2 " \times 4$ " printed circuit board and a high-intensity one (a closely mounted LED array which had 90 LED in the same PCB, about $0.76 \mathrm{~cm}$ apart). The maximum intensity achieved by two high-intensity units (one on each side of the PBR) was $50 \mathrm{~mW} / \mathrm{cm}^{2}$ by providing a power of $2.4 \mathrm{~V}$ per LED. However, the PBR were normally powered at $2.1 \mathrm{~V} /$ device to give a light in-

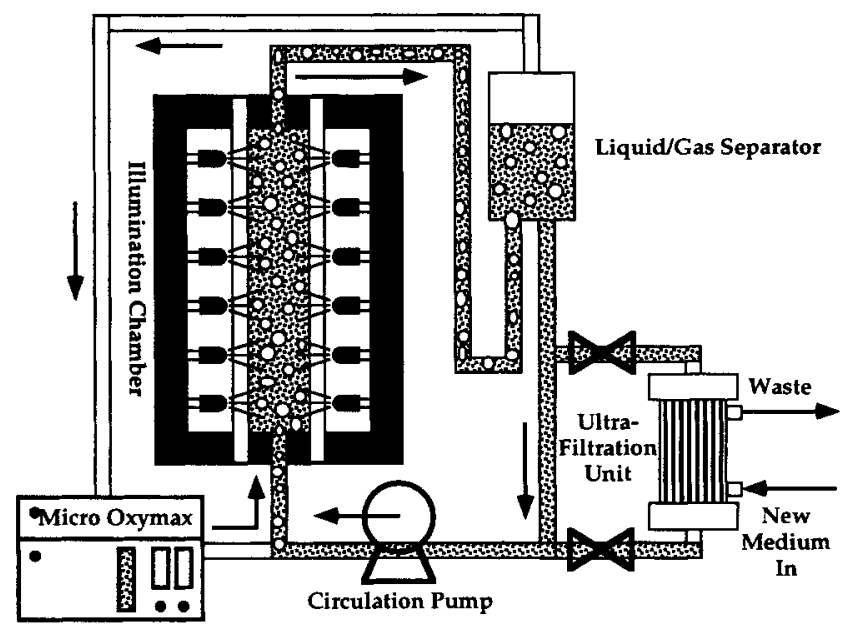

Figure 1. Schematic diagram of the LED-based prototype PBR that uses internal sparging and on-line ultrafiltration. tensity inside the PBR of $23 \mathrm{~mW} / \mathrm{cm}^{2}$. All the experiments were performed at a constant temperature of $25^{\circ} \mathrm{C}$ and initial $\mathrm{pH}$ of 6.2 , and were done batch-wise with $\mathrm{N}-8$ medium. A peristaltic pump was used to circulate the culture medium and to keep the cells in suspension. Premixed gas with the composition of $15 \% \mathrm{O}_{2}, 5 \% \mathrm{CO}_{2}$, and balanced with $\mathrm{N}_{2}$ was introduced through the gas analyzer and refreshed whenever either $\mathrm{O}_{2}$ or $\mathrm{CO}_{2}$ concentration had changed more than $0.5 \%$ from the premixed concentration.

The seed culture was prepared by $500-\mathrm{mL}$ flasks with 150 -mL working volume using an LED unit with 65 of 680 $\mathrm{nm}$ LED. The flask was doubly wrapped with extra-heavyduty aluminum foil to block the ambient lights.

\section{Cell Analysis}

Samples were prepared by diluting the cell culture broth with the appropriate amount of isotonic diluent (Fisher Scientific, Pittsburgh, PA). The cell concentration was determined by a microprocessor-controlled electronic particle counter, Coulter Counter model ZM with a Channelizer model C256 (both from Coulter Electronics, Inc., Hialeah, FL) as well as by occasional confirming counts using a hemacytometer. Since the average cell size was highly variable (about $100 \mathrm{fL} /$ cell or $\mu \mathrm{m}^{3} /$ cell while the cells are actively growing and about $30 \mathrm{fL} /$ cell at stationary phase), the total cell volume $[=$ cell concentration $($ cells $/ \mathrm{mL}) \times$ average cell volume $(\mathrm{fL} / \mathrm{cell})]$ was used to calculate the volumetric specific growth rate and thus the doubling time.

\section{Gas Composition Measurement}

The gas concentrations were measured by a Micro-Oxymax gas analyzer (Columbus Instruments, Columbus, $\mathrm{OH}$ ). This system was chosen due to its high sensitivity to detect the small gas composition change by $100 \mathrm{~mL}$ of algal culture. To obtain the desirable sensitivity, a slightly pressured closed system in which the air in the gas phase of a test chamber is pumped through the gas sensors and then returned to the test chamber, was necessary. The $\mathrm{O}_{2}$ and $\mathrm{CO}_{2}$ gas concentrations in the air in the test chamber were measured periodically, and the changes in the concentrations as well as the volumes of the algal culture and gaseous phase were used to compute gas consumption or production rates. Whenever the concentration of either gas in the closed gas loop deviated more than $\pm 0.5 \%$, the gas phase was refreshed from a gas cylinder with the premixed gas. A reference chamber containing a reference supply of air was used to recalibrate the sensors prior to each measurement. The oxygen sensor operated as an oxygen battery (fuel cell) and the carbon dioxide sensor was a single-beam nondispersive infrared device.

\section{RESULTS AND DISCUSSION}

\section{Performance of the Prototype PBR}

A schematic diagram of prototype PBR with internal sparging with gas/liquid separator is shown in Figure 1. A typical 
growth curve in this PBR with low light-intensity units (a 24-LED unit on each side, $1.55 \mathrm{~cm}$ apart each other) is shown in Figure 2 (closed symbols). Ultrafiltration (UF) was used to semicontinuously feed the nutrients without removing cells from the PBR system. The first ultrafiltration was performed at $92.3 \mathrm{~h}$ and the average cell size immediately increased. This means that cells actively divided. UF was performed every other day starting at 115.5 $\mathrm{h}$, where the average cell size started to increase again. The successive UF did not show the same visible effect as the first two. However, it was necessary to keep the cells alive. The volume of fresh medium used by each UF was 2- to 4 -fold of the total PBR volume, depending on cell concentration. The specific growth rate in the logarithmic phase was $0.035 \mathrm{~h}^{-1}$ (a doubling time of $20 \mathrm{~h}$ ), resulting in a maximum cell density at the end of the operation of more than $2 \%(\mathrm{v} / \mathrm{v})$. However, it took over $350 \mathrm{~h}$ to increase the cell concentration from $1 \cdot 10^{8}$ (at $140 \mathrm{~h}$ ) to $8 \cdot 10^{8}$ (closed symbols). This growth was extremely slow because a 100 fold increase in cell number could be achieved in about 100 $\mathrm{h}$ following the initial lag phase.

Monitoring the oxygen production rate was challenging. The gas analyzer required a hermetically sealed loop to measure the gas composition, and on-line ultrafiltration was required to support cell concentration greater than $1 \cdot 10^{8}$ cells $/ \mathrm{mL}$. Even though the setup was carefully designed to measure gas concentration, the gas reading (oxygen production rate per $\mathrm{L}$ culture, $\mathrm{OPR} / \mathrm{L}$ ) fluctuated whenever the gas loop was disturbed by cell sampling, UF, or to refresh the gases in the hermetically sealed gas loop. The highest oxygen production rate achieved in this configuration (the PBR with low-intensity LED units and $1.55-\mathrm{cm}$ light path) was about $2 \mathrm{mmol} / \mathrm{L}$ culture/ $\mathrm{h}$ at $150 \mathrm{~h}$ (dotted line in Fig. 3). The second peak in OPR/L at $330 \mathrm{~h}$ was a result of increasing the power to the LED units to $2.4 \mathrm{~V}$. By applying this voltage, the light intensity could be increased about

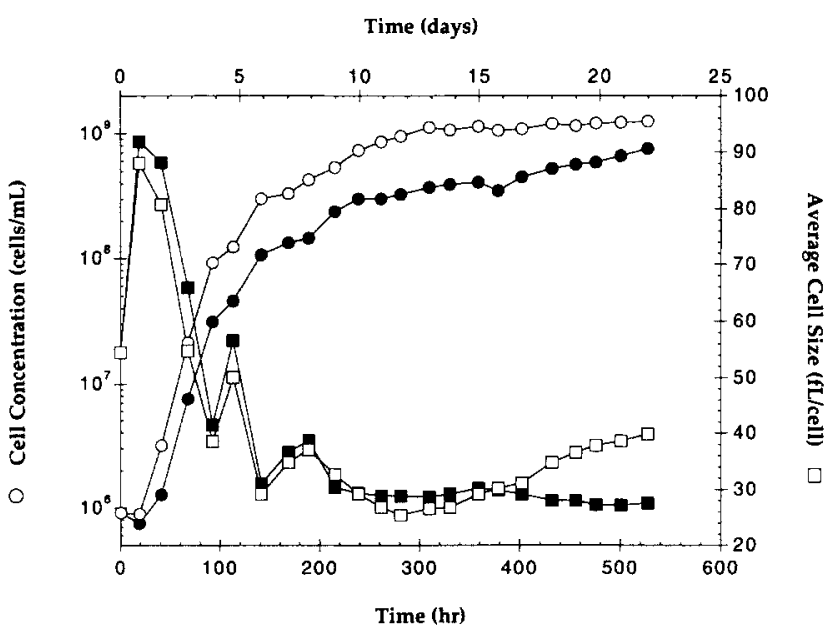

Figure 2. The growth curves $(O$ and $\boldsymbol{O}$, cells $/ \mathrm{mL})$ and corresponding average cell sizes ( $\square$ and $\square$, fL/cell) in the two different light intensities. Closed symbols for the low-intensity (48 LED/chamber or 24 LED/ illuminating surface) and open markers for high-density LED units (180 LED/chamber $=90$ LED each on both sides).

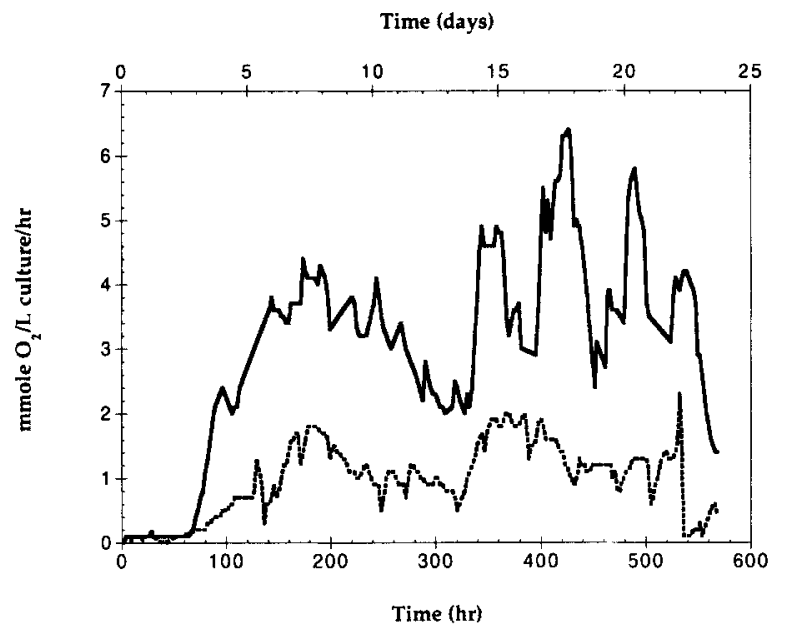

Figure 3. Oxygen production comparison between low-intensity (----) and high-intensity ( $\rightarrow$ PBR from the same conditions as in Figure 2.

$100 \%$ (more than $40 \mathrm{~mW} / \mathrm{cm}^{2}$ ). However, this voltage was not within the normal operating range of the LED used. Therefore at $2.4 \mathrm{~V}$, the LED generated a significant amount of heat and finally some of the individual LED were burned out. All the later experiments used $2.1 \mathrm{~V}$ as the maximum power.

These results implied that this prototype PBR was operating in a light-limiting environment. High efficiency in light absorption of algae resulted in uneven accessibility to the incident light or mutual shading. Perfect mixing would overcome this limitation. A high degree of mixing generally introduces a high degree of shear stress, to which algae are sensitive. ${ }^{11}$ Another way to address the light-limitation was to deliver more photons to overcome mutual shading. Highintensity LED assemblies were constructed by increasing the number of LED per unit (to $90 \mathrm{LED} /$ unit) rather than increasing the power supplied to each unit.

\section{Modifications to Improve the Performance of the PBR}

The original low-intensity LED units were replaced by two high-intensity units $1.55 \mathrm{~cm}$ apart from each other. The expected change in cell growth was obtained (open symbols in Fig. 2). The higher number of LED could support a cell concentration of $1.2 \times 10^{9}$ cells $/ \mathrm{mL}(\approx 5 \% \mathrm{v} / \mathrm{v})$ and a specific growth rate during the exponential phase of $0.046 \mathrm{~h}^{-1}$ (a doubling time of $15 \mathrm{~h}$ ). The 2.5-fold difference in the total biomass (\% v/v) between a low-intensity PBR and a high-intensity one was consistently observed in several independent experiments. The difference in the total biomass was smaller than the difference in the light intensity, which was 3.75-fold. Again, once the culture entered the stationary phase, the growth rate dropped significantly and the culture was able to grow to very high cell concentrations only if a series of UF were performed.

The peak oxygen production rate at the end of the logarithmic phase $(170 \mathrm{~h}$ ) was about $4.5 \mathrm{mmol} / \mathrm{L}$ culture $/ \mathrm{h}$ (solid 
line in Fig. 3). A higher rate of up to $6 \mathrm{mmol} / \mathrm{L}$ culture/h could be obtained by the higher voltage ( $2.4 \mathrm{~V}$; see previous section) at $430 \mathrm{~h}$. This was a 3-fold increase over the performance obtained by using the original lower-intensity LED units in the PBR. The ratio of improvement was smaller than the ratio of light intensity, suggesting that even at the higher light intensity the PBR eventually became light-limited.

A final design modification was to reduce the crosssection of the PBR to allow the light to penetrate the entire culture volume inside the PBR. The depth of the culture (or the distance between the two illuminating surfaces) was $1.55 \mathrm{~cm}$ in all the PBR mentioned before. A PBR with a shorter light path of $1.00 \mathrm{~cm}$ and two high-intensity LED units was constructed. Figure 4 shows the growth data from an experiment with the new PBR (open symbols) and a PBR with original thickness with high density (closed symbols). A specific volumetric growth rate of $0.058 \mathrm{~h}^{-1}$ (a doubling time of $12 \mathrm{~h}$ ) in exponential phase and a final cell concentration greater than $2 \times 10^{9}$ cells $/ \mathrm{mL}$ (more than $6.6 \% \mathrm{v} / \mathrm{v}$ ) were obtained in the PBR with the reduced depth. By reducing the light path by $35 \%$, there was a 2 -fold increase in the maximal cell density, and the exponential growth rate was increased by $20 \%$. Thus, a comparable cell concentration to the highest algal cell concentration reported ${ }^{33}$ was achieved by monochromatic red lights from LED.

A similar improvement in OPR/L was obtained (solid line in Fig. 5), whose peak production rate was $10 \mathrm{mmol} / \mathrm{L}$ culture/h at $105 \mathrm{~h}$. The SOPR at this point was less than 20 $\mathrm{fmol} / \mathrm{cell} / \mathrm{h}$ at a cell density of about $5 \cdot 10^{8}$ cells $/ \mathrm{mL}$. This result re-emphasizes the need to distribute the light more evenly to individual cells. Better light distribution could be obtained by either (1) achieving a higher degree of fluid mixing without damaging the cells, or (2) reducing the culture depth.

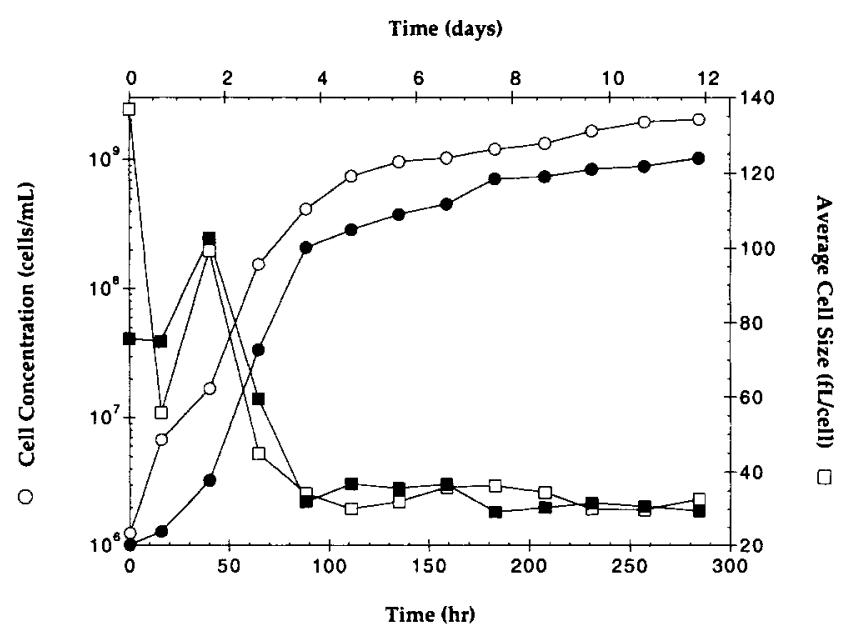

Figure 4. The cell concentration ( $O$ and $O$, cells $/ \mathrm{mL})$ and the average cell size ( $\square$ and $\square$, fL/cell) of the original PBR (closed symbols, thickness of the illumination chamber: $1.55 \mathrm{~cm}$ ) and PBR with thinner illumination chamber (open symbols, thickness: $1.0 \mathrm{~cm}$ ).

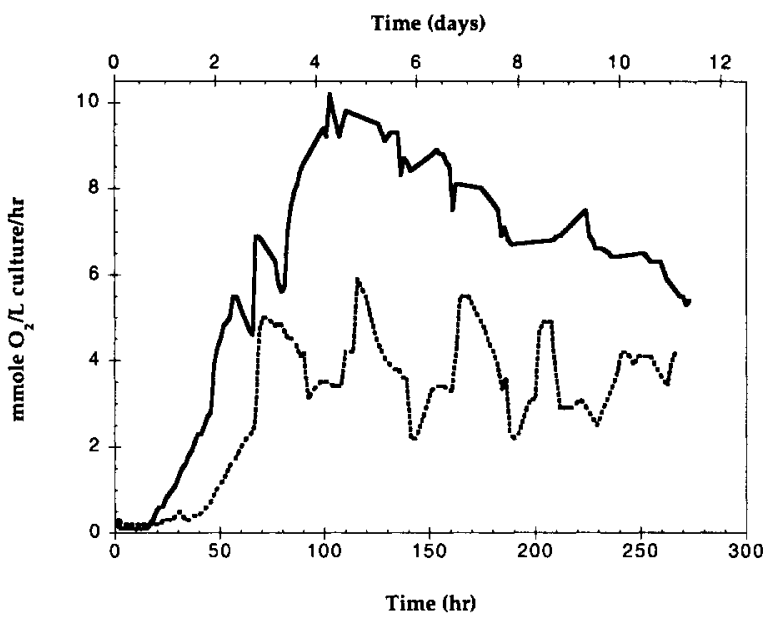

Figure 5. The oxygen production rates in a thicker PBR (---) and a thinner PBR (-), both with high light intensity (180 LED/PBR). Conditions the same as in Figure 4.

\section{CONCLUSION}

LED-based photobioreactor systems were designed, constructed, and tested to achieve high-density photoautotrophic algal cultures. These PBR used LED emitting at 680 $\mathrm{nm}$ as the sole light source. The LED units were located internally for direct illumination and could emit the photosynthetic photon flux of up to $50 \mathrm{~mW} / \mathrm{cm}^{2}$. By introducing (1) internal sparging (which improves overall light utilization), (2) on-line ultrafiltration (supplying medium components semicontinuously while removing any secondary metabolites), (3) higher light intensity (increasing the number of LED per illumination area), and (4) a shorter light path, both the highest cell concentration (more than $2 \times 10^{9}$ cells $/ \mathrm{mL}$ ) and the highest total cell volume fraction (more than $6.6 \% \mathrm{v} / \mathrm{v}$ ) were achieved. By modifying these four factors, the oxygen production rate in the final PBR was increased almost 5-fold from the initial PBR, giving the maximal oxygen production rate of $10 \mathrm{mmol}$ oxygen/L culture/h. Further challenges are to improve light distribution and continuously perfuse fresh medium of the proper composition to reach the stated goal of a SOPR of $100 \mathrm{fmol} /$ cell $/ \mathrm{h}$ at a cell concentration of $1 \cdot 10^{9}$ cells $/ \mathrm{mL}$.

This project was funded in part by Grant $10-56943$ from NASA.

\section{References}

1. Barta, D. J., Tibbitts, T. W., Bula, R. J., Morrow, R. C. 1990. Application of light emitting diodes for plant irradiation in space bases. COSPAR Meeting in The Hague, The Netherlands, June 28, 1990.

2. Beardall, J. 1985 . Occurrence and importance of $\mathrm{HCO}_{3}{ }^{-}$utilization in microscopic algae, pp. 83-96. In: W. J. Lucas and J. A. Berry (eds.), Inorganic carbon uptake by aquatic photosynthetic organisms. American Society of Plant Physiologists, Rockville, MD.

3. Benemann, J. R., Koopman, B. L., Weissman, J. C., Eisenberg, D. E., Goebel, R. P. 1980. Development of microalgae waste water treatment and harvesting technologies in California, pp. 457-496. In: G. Shelef and C. J. Soeder (eds.), Algae biomass: Production and use. Elsevier/North-Holland Biomedical Press, Amsterdam, Holland. 
4. Borowitzka, M. A., Borowitzka, L. J. 1988. Micro-algal biotechnology. Cambridge University Press, Cambridge, U.K.

5. Burgess, J. G., Iwamoto, K., Miura, Y., Takano, H., Matsunaga, T. 1993. An optical fiber photobioreactor for enhanced production of the marine unicellular alga lsochrysis aff. Galbana T-Iso (UTEX LB 2307) rich in docosahexaenoic acid. Appl. Microbiol. Biotechnol. 39: 456-459.

6. Darnall, D. W., Greene, B., Henzi, M. T., Hosea, J. M., McPherson, R. A., Snedson, J., Alexander, M. D. 1986. Selective recovery of gold and other metal ions from an algal biomass. Environ. Sci. Technol. 20: 206-208.

7. Faulkner, D. J. 1986. Marine natural products. Nat. Prod. Rep. 3: $1-31$.

8. Finn, R. K. 1954. Agitation-aeration in the laboratory and in industry. Bacteriol. Rev. 18: 254-274

9. Glombitza, K. W., Koch, M. 1989. Secondary metabolites of pharmaceutical potential, pp. 161-238. In: R. C. Cresswell, T. A. V. Rees, and H. Shah (eds.), Algal and cyanobacterial biotechnology. Longman Scientific \& Technical, Harlow, UK.

10. Greene, B., Henzi, M. T., Hosea, J. M., Darnall, D. W. 1986. Elimination of bicarbonate interference in the binding of U(VI) in millwaters to freeze-dried Chlorella vulgaris. Biotechnol. Bioeng. 28: 764-767.

11. Gudin, C., Chaumont, D. 1991. Cell fragility-the key problem of microalgae mass production in closed photobioreactor. Bioresource Technol. 38(2-3): 145-151.

12. Hill, R., Bendall, F. 1960 . Function of the two cytochrome components in chloroplasts: a working hypothesis. Nature 186: 136-137.

13. Hoppe, H. A., Levring, T., Tanaka, Y. 1979. Marine algae in pharmaceutical science. Walter de Gruyter, Berlin, Germany

14. Hosea, M., Greene, B., McPherson, R., Henzel, M., Alexander, M. D., Darnall, D. W. 1986. Accumulation of elemental gold on the alga Chlorella vulgaris. Inorg. Chim. Acta 123: 161-165.

15. Javanmardian, M., Palsson, B. O. 1991. High-density photoautotrophic algal cultures: design, construction, and operation of a novel photobioreactor system. Biotechnol. Bioeng. 38: 1182-1189.

16. Javanmardian, M., Palsson, B. O. 1992. Continuous photoautotrophic cultures of the eukaryotic alga Chlorella vulgaris can exhibit stable oscillatory dynamics. Biotechnol. Bioeng. 39: 487-497.

17. Javanmardian, M., Palsson, B. O. 1992. Design and operation of an algal photobioreactor system. Adv. Space Res. 12: 231-235.

18. Kargi, F., Moo-Young, M. 1985. Transport phenomena in bioprocesses, pp. 5-56. In: M. Moo-Young (ed.), Comprehensive biotechnology, vol. 2. Pergamon Press, Oxford, U.K.

19. Kessler, E., Huss, V. A. R. 1992. Comparative physiology and biochemistry and taxonomic assignment of the Chlorella (Chlorophyceae) strains of the culture collection of the University of Texas at Austin. J. Phycol. 28: 550-553.

20. Kok, B. 1960. Efficiency of photosynthesis, pp. 566-633. In: W. Ruhland (ed.), Encyclopedia of plant physiology. Springer, Berlin, Germany.

21. Langhans, R. W., Dreesen, D. R. 1988. Challenges to plant growing in space. HortScience 23: 286-293.

22. Lee, E. T.-Y., Bazin, M. J. 1990. A laboratory scale air-lift helical photobioreactor to increase biomass output rate of photosynthetic algal cultures. New Phytol. 116: 331-335.

23. Metting, B. 1988. Micro-algae in agriculture, pp. 288-304. In: M. A. Borowitzka and L. J. Borowitzka (eds.), Micro-algal biotechnology. Cambridge University Press, Cambridge, U.K.

24. Mignot, L., Junter, G. A., Labbe, M. 1989. A new type of immobilized-cell photobioreactor with internal illumination by optical fibers. Biotechnol. Techniques 3: 299-304.

25. Miller, R. L. 1969. Design and preliminary evaluation of a man-rated photosynthesis exchanger. USAF School of Aerospace Medicine, SAM-TDR-69-64, Brooks AFB, TX.

26. Miyamoto, K., Wable, O., Benemann, J. R. 1988. Vertical tubular reactor for microalgae cultivation. Biotechnol. Lett. 10: 703-708.
27. Mori, K. 1985. Photoautotrophic bioreactor using solar rays condensed by fresnel lenses. Biotechnol. Bioeng. Symp. 15: 331-345.

28. Myers, J. 1980. On the algae: thoughts about physiology and measurements of efficiency, pp. 1-16. In: P. G. Falkowski (ed.), Primary productivity in the sea. Plenum Press, New York.

29. Myers, J., Graham, J. 1971. The photosynthetic unit in Chlorella measured by repetitive short flashes. Plant Physiol. 48: 282-286.

30. Nielsen, E. S. 1966. The uptake of free $\mathrm{CO}_{2}$ and $\mathrm{HCO}_{3}{ }^{-}$during photosynthesis of plankton algae with special reference to the coccolithophorid Coccolithus huxleyi. Physiol. Plant. 19: 232-240.

31. Olson, R. L., Oleson, M. W., Slavin, T. J. 1988. CELSS for advanced manned mission. HortScience 23 : 275-286.

32. Pirt, S. J., Lee, Y.-K., Richmond, A., Watts-Pirt, M. 1980. The photosynthetic efficiency of Chlorella biomass growth with reference to solar energy utilization. J. Chem. Tech. Biotechnol. 30: 25-34.

33. Pirt, S. J., Lee, Y.-K., Walach, M. R., Pirt, M. W., Balyuzi, H. H. M., Bazin, M. J. 1983. A tubular photobioreactor for photosynthetic production of biomass from $\mathrm{CO}_{2}$ : design and performance. J. Chem. Tech. Biotechnol. 33B: 35-58.

34. Pratt, R. 1944. Studies on Chlorella vulgaris. IX. Influence on growth of Chlorella of continuous removal of chlorellin from the culture solution. Am. J. Bot. 31: 418-421.

35. Pratt, R., Daniels, T. C., Eiler, J. B., Stain, H. H. 1944. Chlorellin, an antibacterial substance from Chlorella. Science 99: 351-352.

36. Ratchford, I. A. J., Fallowfield, H. J. 1992. Performance of a flat plate, air-lift reactor for the growth of high biomass algal cultures. J. Appl. Phycol. 4: 1-9.

37. Richmond, A. 1986. Microalgae of economic potential, pp. 199-243. In: A. Richmond (ed.), Handbook of microalgal mass culture. CRC Press, Boca Raton, FL.

38. Schreiber, U. 1983. Chlorophyll fluorescence yield changes as a tool in plant physiology. I. The measuring system. Photosynth. Res. 4: 361-373.

39. Shinho, K. 1986. Antitumor glycoproteins from Chlorella and other species. Jpn. Kokai Tokkyo Koho Japanese patent JP 61-069728, 105 030034t.

40. Steranka, F. M., DeFevere, D. C., Camras, M. D., Tu, C.-W., McElfresh, D. K., Rudaz, S. L., Cook, L. W., Snyder, W. L. 1988. Red AlGaAs light-emitting diodes. Hewlett-Packard J. 39: 84-88.

41. Takano, H., Takeyama, H., Nakamura, N., Sode, K., Burgess, J. G., Manabe, E., Hirano, M., Matsunaga, T. 1992. $\mathrm{CO}_{2}$ removal by high-density culture of a marine cyanobacterium Synechococcus sp. using an improved photobioreactor employing light diffusing optical fibers. Appl. Biochem. Biotechnol. 34/35: 449-458.

42. Torzillo, G., Carlozzi, P., Pushparaj, B., Montaini, E., Materassi, R. 1993. A two-plane tubular photobioreactor for outdoor culture of Spirulina. Biotechnol. Bioeng. 42: 891-898.

43. Treat, W. J., Castillon, J., Soltes, E. J. 1990. Photobioreactor culture of photosynthetic soybean cells: growth and biomass characteristics. Appl. Biochem. Biotechnol. 24/25: 497-510.

44. Tredici, M. R., Materassi, R. 1992. From open ponds to vertical alveolar panels: the Italian experience in the development of reactors for the mass cultivation of phototrophic microorganisms. J. Appl. Phycol. 4: 221-231.

45. Vonshak, A. 1986. Laboratory techniques for the cultivation of microalgae, pp. 117-145. In: A. Richmond (ed.), Handbook of microalgal mass culture. CRC Press, Boca Raton, FL.

46. Walker, D. A. 1989. Automated measurement of leaf photosynthetic $\mathrm{O}_{2}$ evolution as a function of photon flux density. Phil. Trans. R. Soc. Lond. B323: 313-326.

47. Wang, S. C., Jin, M. R., Hall, D. O. 1991. Immobilization of Anabaena azollae in hollow fibre photobioreactors for ammonia production. Bioresource Technol. 38(2-3): 85-90.

48. Yongmanitchai, W., Ward, O. P. 1992. Growth and eicosapentaenoic acid production by Phaeodactylum tricornutum in batch and continuous culture systems. JAOCS 69: 584-590. 